\title{
The Research on the Infantry of the Tang Dynasty
}

\author{
Cheng XING ${ }^{1, *}$ \\ ${ }^{1}$ Northeastern University, Shenzhen, Guangdong Province 518038, China \\ ${ }^{*}$ Corresponding author. Email: 20175669@stu.neu.edu.cn
}

\begin{abstract}
The Tang Dynasty (618-907) was one of the most powerful dynasties in the history of China. This thesis would try to research one of the most important forces of its army - infantry, helping us find out the reason why the infantry of the Tang Dynasty could become powerful and keep its combat effectiveness until the end of the Tang Dynasty. During the whole 289 years, the wars between the Tang Dynasty and the neighbouring countries never stop, making the Tang army keep developing. After the An-Shi Rebellion (755-763), the Tang army especially its mounted troops started to go downhill. However, the infantrymen still performed well in the next wars. They let the Tang Dynasty avoid being destroyed by foreigners. Finally, the Tang Dynasty was terminated by its generals. In this process, these generals had a series of fierce battles. In these battles, infantry also acted as an important role.
\end{abstract}

Keywords: The Tang Dynasty, Infantry, Mansion Army System, Military commissioner

\section{INTRODUCTION}

People usually spend too much time on cavalry when having a study on the military history of the Tang Dynasty. Not only the Tang Dynasty, those powerful countries of that era such as Turkic and Byzantine were also famous for their cavalry. We need to admit that the Tang army's cavalries got a series of brilliant victories. Most of the famous generals of the Tang Dynasty were excellent cavalry commanders. But without their strong supporter - infantry, the result would become uncertain. It is an important point that is usually ignored by researchers. There's no doubt that the Tang army's infantry was absolutely first-rate at that time because of the advanced equipment and military system. Their new weapons and new organization greatly influenced the following dynasties. It was the result of the Tang Dynasty's nonstop expansion.

Before introducing the Tang Dynasty's infantry, I need to point out a bad phenomenon that appears in the study of Chinese military history. Because of some causes, reverse nationalism has widely spread in China. Naturally, historical research is greatly affected. Since infantry was the main force of Han nationality's army, it was always belittle by those "experts" and "scholars". However, because these "experts" and "scholars" are short of professional knowledge, their articles will make the real experts laugh. For example, they belittle infantry and overstate the role of cavalry. At the same time, they also belittle heavy cavalry and tout horse archers. Simply because horse archers were the main force of Han nationality's enemies. Until today, many Chinese people are still misled by this mistaken view. However, ancient Chinese people clearly recorded that the bows used by cavalry only had a range of less than 40 meters, much shorter than the range of infantry's bows.

Fortunately, I myself avoid being influenced by reverse nationalism when researching the infantry of the Tang Dynasty. The real difficulty I met was the lack of antiques. Many weapons made of metal disappeared in history. Therefore, our best references were some paintings and statues. Fortunately, the history records of the Tang Dynasty were really detailed. With the help of these words, we can restore the original visage of the Tang army's infantry.

This paper's purpose was to find out the reason why the infantry of the Tang dynasty was more powerful than other countries at that time through analyzing their equipment, tactics, and performance on the battlefield.

\section{HISTORICAL BACKGROUND}

\subsection{The reformation of infantry}

Heavy cavalry was very popular in the Northern and Southern Dynasties (420-589). In this period, cavalries usually used lances and swords as their weapons. Both they themselves and their horses wore heavy armor (as shown in Figure 1). Ancient Chinese people gave them a 
name "Jiaqijuzhuang". According to The history of Song Dynasty (1345), "Jiaqi" was the armor of the soldier and "Juzhuang" was the armor of the horse [1].

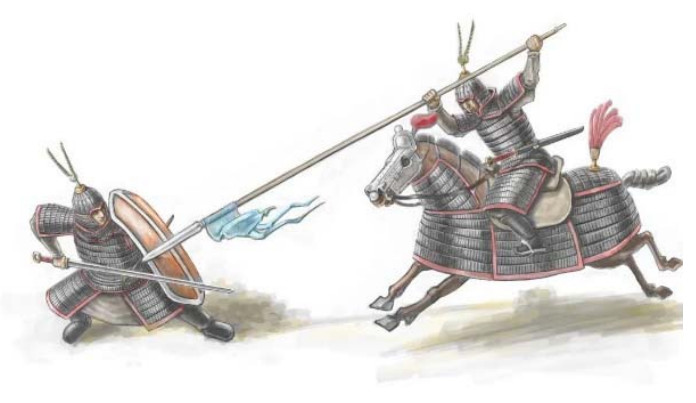

Figure 1 A Jiaqijuzhuang attacked an infantryman [2].

From the picture we can easily see that it was hard for infantrymen to fight back when facing Jiaqijuzhuang if they were just equipped with swords and shields. In order to fight against the heavy cavalries, the infantry's spears of that period became longer and longer. This change greatly influenced the following dynasties. At the same time, the armor of the infantry was heavier than the dynasties before. In the Sui Dynasty (581-618), the development of infantry maintained this trend because Jiaqijuzhuang was still the leading role of that period.

After coming to the Tang Dynasty, the nomads from the north became the largest threat, making the infantry have to make some changes. As we all know, the nomads were skillful horse archers. The infantry of the early Tang Dynasty kept using spears as primary weapon. At the same time, in order to gain an advantage in the battlefield, most of the infantry would be equipped with bows. About ten to twenty percent of them would be equipped with crossbows [3].

Besides, in order to better cooperate with the cavalry, the Tang Dynasty's infantrymen would take a chariot when they were on the way to the battlefield.

\subsection{The threat of nomads}

Turkic was a nomadic regime rose from the Mongolian Plateau. After a series of wars, it defeated the overlord of grassland - Rouran, becoming the new governor of that area. The name Turkic first appeared in The history of the Northern Zhou Dynasty(636) [4]. The origin of this nation totally has five different statements [5]. In the early Tang Dynasty, Turkic had broken up. The one confronted with the Tang army was called Eastern Turkic Khanate. At that time, Eastern Turkic Khanate was at the height of its power, owning a huge army consisting of more than a million soldiers [6]. The cavalries of the Eastern Turkic Khanate were really famous. After Jin Yang Mutiny, the Khan of Eastern Turkic sent five hundred cavalries to help Li Yuan (566-
635) [7]. After Li Yuan built the Tang Dynasty, the Turkic Khan still kept asking for property from him. In 626, the army of Eastern Turkic Khanate started to invade the territory of the Tang Dynasty. Emperor Tang Taizong (598-649) had to sign a covenant with Turkic [6].

The threat from the north let the Tang Dynasty keep developing its military force. In 630, a famous general named Li Jing (571-649) let the Turkic Khan become the Tang army's captive in the battle of the Yinshan Mountains. After that, the Tang army kept having wars with the regimes built by nomads such as Seyanto and Western Turkic Khanate. In this period, some generals of the Tang Dynasty such as Su Dingfang (597-667) and his student Pei Xingjian (619-682) did their level best to develop the infantry and cavalry cooperation tactic which greatly influenced the Five Dynasties and Ten States period (902-979) and the Song Dynasty (960-1279).

\subsection{The times of guard army}

After An-Shi Rebellion, the troops of central army started to reduce. Therefore, military commissioners (they were called Jiedushi in Chinese) and their armies became the main force of the Tang Dynasty. A military commissioner named Tian Chengsi (705-779) built a private army consisting of ten thousand elite soldiers to act as his bodyguards [8]. These soldiers were called Yabing [8]. Tian opened a new era of the Tang army. After that, many military commissioners started to build their own guard armies. At the same time, Yabing became the name of guard armies' soldiers.

However, powerful guard armies might become a threat to their commanders. For example, in the late Tang Dynasty, a military commissioner named Zhou Bao (814887 ) once set another guard army named Qinjun, trying to make a balance between military commissioner and Yabing. However, these two guard armies finally betrayed him at the same time.

What's worse, it was hard for Yabing to keep a good discipline, which made civilians hate them very much.

Though guard armies had many disadvantages, they were still the most important military force of the late Tang Dynasty. Nearly all the generals of that era relied on their powerful combat effectiveness. These generals gave preferential treatment to these soldiers and used some cool names to name these armies.

This special military system greatly influenced the following dynasties. Until the Ming Dynasty (13681644), the Jiading system still had the shadow of it. 


\section{THE MILITARY SYSTEM OF THE TANG DYNASTY'S INFANTRY}

\subsection{A typical army of the Tang Dynasty}

A historian named Du You (735-812) recorded some tactics created by General Li Jing in his Tong Dian (801), including the components of a typical army of the early Tang Dynasty. It was the best reference for us when researching the military system of the Tang army.

In the early Tang Dynasty, a typical army led by a general usually consisted of four thousand cavalries and ten thousand infantrymen [9]. Besides, the baggage troops of this army usually consisted of six thousand soldiers [9].

The ten thousand infantrymen could be divided into four parts: archers (2,200 people), crossbowmen (2,000 people), shock brigade (2,900 people) and mobile troops (2,900 people).

Compared with the dynasties before, the proportion of the crossbowmen of the Tang army clearly reduced. In order to get mobility, the Tang army gave up a famous weapon named Wugangche, a wheelbarrow with a big shield. This special wheelbarrow could stop the cavalries from shocking the infantry. The infantrymen could stand behind the big shield and shoot the cavalries with their crossbows. In the Han Dynasty (202B.C.-A.D.220), a famous general named Wei Qing once used this tactic, creating massive loss to the cavalries of Xiongnu in the battle of Mobei (an important battle between the Han Dynasty and Xiongnu, happened in 119B.C.) [11]. However, the firing rate of crossbows was slower than that of the bows. Without the cover of Wugangche, the crossbowmen would be at a disadvantage when facing cavalries. So the crossbowmen of the Tang army would use clubs and glaives (as shown in Figure 2) as melee weapons [9].

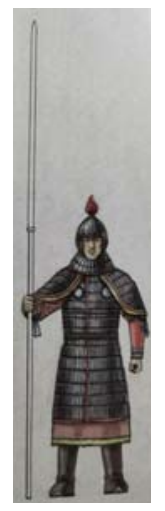

Figure 2 A Tang Dynasty's warrior with his Modao (a special kind of glaive) [2].

A few decades later, the situation was a little different. In a military work named Taibai Yinjing written by $\mathrm{Li}$ Quan (?-?), a military theorist in the period of Emperor
Tang Xuanzong (685-762), there were 12,500 infantrymen in a typical army of the Tang Dynasty [10]. Each of them was equipped with spears and bows. One fifth of them were equipped with crossbows. Sixty percent of them would wear armor [10].

After coming to the late Tang Dynasty, the components of every army became diverse because military commissioners had their own thoughts. In this period, many little armies consisted of elite soldiers appeared. For example, a general named Yang Xingmi (852-905) owned a little army named Dark Cloud Army. All the soldiers of this army were skillful swordsmen. I will introduce this famous army in detail later.

\subsection{The conscription system of the Tang Dynasty}

In the early Tang Dynasty, the most common conscription system was called Mansion Army System. This system was created by Yuwen Tai (507-556), a strategist of the Western Wei Dynasty (535-556).

In peacetime, the soldiers would work as farmers. At the same time, they needed to learn some military skills such as archery, swordsmanship and horsemanship. When the war came, they would join in the army. The ones who did well in archery and horsemanship would serve as cavalries. Others would serve as infantrymen. These soldiers were under the management of Zhechongfu, a special military department in the Tang Dynasty. Under this system, the main sources of troops were the small landlords. Military exploits were the best way for them to improve their social position. That's why they always fought bravely on the battlefield.

At the beginning of Mansion Army System's establishment, the government asked the soldiers to prepare swords and bows for themselves [12]. The government would provide spears, armor and crossbows for them [12]. The early Tang Dynasty also adopted this system.

In the period of Emperor Tang Xuanzong, this system was replaced by mercenary system. Actually, in the early Tang Dynasty, the government adopted Mansion Army System and mercenary system at the same time. But the government paid more attention to the Mansion Army System. However, in the middle of the eighth century, the Mansion Army System started to have no ability to provide qualified troops. Finally, in 749, the Mansion Army System was stopped by Emperor Tang Xuanzong. After that, mercenary system became the main conscription system until the end of the Tang Dynasty. 


\section{THE EQUIPMENT OF THE TANG DYNASTY'S INFANTRY}

\subsection{The weapons of the Tang Dynasty's infantry}

\subsubsection{Spears}

In both Eastern countries and Western countries, spears were the most faithful friends of ancient infantrymen. In China, bronze spears first appeared in the Shang Dynasty (1600 B.C.-1046 B.C.) [13]. As time goes on, the material of Chinese spear changed from bronze to iron. At the same time, the shape of spears also started to change. Different shapes make the spears have different names in Chinese.

The first kind of spear was called Mao in Chinese (as shown in Figure 3). It was a kind of weapon widely used in both Bronze Age and Iron Age. In the Qin and Han Dynasties, it started to take the place of dagger-axe, becoming the most important long weapon of Chinese soldiers.

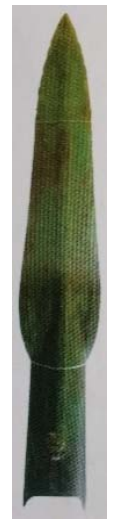

Fig 3 The head of Mao [13].

The second one was called Shuo, which was a special kind of Mao. Compared with Mao, the head of Shuo was much longer, making it get the ability to break the armor easily. The head of Shuo is usually fifty to sixty centimeters in length. In the Northern and Southern Dynasties, it was widely used by heavy cavalries. In the Tang Dynasty, since the cavalries liked charging, Shuo was still of great importance. Many famous generals such as Yuchi Gong, Qin Qiong and Cheng Zhijie were recorded as skillful users of it [6] [8]. Some Japanese scholars translated Shuo as lance. It was inaccurate. The Shuo used by cavalry was called Mashuo (as shown in Figure 1, the weapon used by the heavy cavalry). It can be translated as lance. However, there was also a kind of Shuo used by infantry which was called Bushuo. We'd better translate it as pike.

The final one was called Qiang, which was the final shape of Chinese style spear. The head of Qiang is a rhombus (as shown in Figure 4), much shorter than that of Mao. Usually, there are some red tassels between the head and the pikestaff which can stop the blood from running from the head to the pike staff. Qiang started to be popular in the Jin Dynasty (265-420), but it couldn't take the place of Mao and Shuo. In the Sui and Tang Dynasties, Qiang became the main weapon of army. According to Taibai Yinjing, every infantryman of the Tang army had a Qiang [10]. Except using it as a weapon, they could use it to make rafts if they couldn't find any boats. Qiang acted as a faithful friend of Chinese soldiers until the end of the Qing Dynasty (1636-1912).

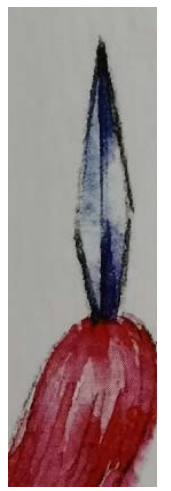

Fig 4 The head and the red tassels of Qiang [13].

These three kinds of spears all appeared in the Tang Dynasty. However, as time goes on, Qiang was demonstrated to be the most useful one.

\subsubsection{Modao}

Modao was a special kind of glaive (as shown in Figure 2). According to Tang Liudian (738), Modao was the horse-chopping sword in ancient times, a kind of glaive, used by infantry [14]. It was the most famous weapon of the Tang Dynasty. It quickly disappeared after the Tang Dynasty. Many people thought that it had been lost. However, the correct explanation was that Modao was modified. Because many new kinds of glaives appeared in the following dynasties. After all, the Song and Ming Dynasties were the golden ages of glaives. According to Wujingzongyao (1044), a military work of the Northern Song Dynasty, there were seven kinds of glaives used by the soldiers of the Song army [15]. Some martial artists of the Ming Dynasty summarized the skills of glaive and recorded them in their books.

About the purpose of Modao, there are two different statements. Some researchers thought that Modao was just a common weapon of heavy infantry. According to a famous general and martial artist named Yu Dayou (1503-1579), a soldier who used glaive would be at a disadvantage when facing a pikeman. Since the length of glaive was much shorter than that of the pike. However, when the distance was close enough (less than three meters), the pikeman would lose his advantage. Other researchers thought that Modao was used to attack the horses of cavalries. More precisely, Modao was used to attacked horses' legs [16]. Actually, glaives really had this 
function. In the battle of Yancheng city, the infantry led by General Yue Fei (1103-1142) adopted the tactic of chopping horses' legs with their glaives, defeating the heavy cavalry of the Jin army [1].

Since Modao was too heavy, it was always used by the strongest warriors. The most famous user was a general of the Tang Dynasty named Li Siye. According to Guangmingjiangzhuan (1643), Li was 2.1 meters in height, having awesome strength [17]. For the researchers from Europe or the United States, a good reference of this kind of physique is the Gregor Clegane in A Song of Ice and Fire. In the battle of Xiangji Temple, Li and his infantry had a heroic performance. I will introduce this battle in detail later.

\subsubsection{Hengdao}

Hengdao was the most common weapon of the Tang Dynasty's soldiers. It was a kind of sword developed from Huanshoudao (as shown in Figure 5). According to Taibai Yinjing, four-fifths of the Tang army's infantrymen used Hengdao as secondary weapon [10]. In Shosoin of Japan, there were some antiques of it (as shown in Figure 6).

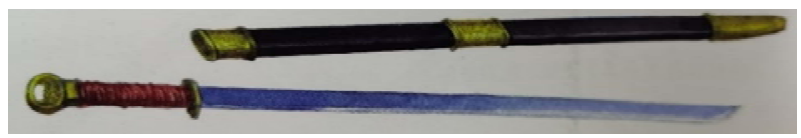

Fig 5 Huanshoudao [13].

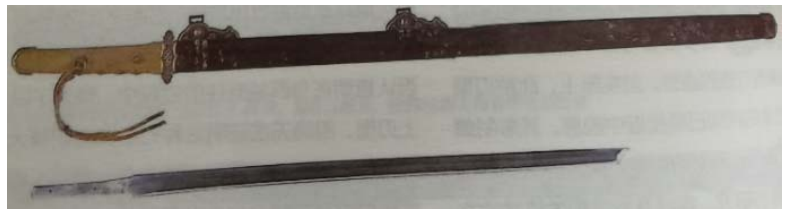

Fig 6 A Hengdao collected in Shosoin of Japan [2].

\subsubsection{Bows and crossbows}

The governors of the Tang Dynasty paid much attention to the archery of soldiers. In the Tang Dynasty, bow was a kind of necessary weapon of infantry. After the military examination was created by Wu Zetian (624$705)$, archery became an essential skill for the people who wanted to be an officer [18].

Compared with bows, the crossbows of the Tang Dynasty were relatively unpopular. Compared with the crossbows of the Han Dynasty, the range of the Tang Dynasty's crossbows was a little longer [3]. However, because of its slow firing rate, the crossbowmen would be at a disadvantage when facing heavy cavalry. However, some commanders of the Tang Dynasty found a good way to deal with this problem. They let the crossbowmen stand in several lines, shooting alternately (as shown in Figure 7). This method was demonstrated to be useful in many battles.

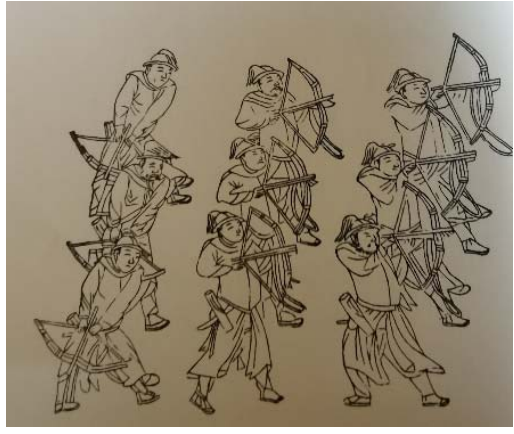

Fig 7 The three-lines tactic of the crossbowmen [13].

The golden age of crossbow was the Song Dynasty. Compared with the Tang Dynasty, the mounted troops of the Song Dynasty greatly reduced. The generals had to use a formation consisting of pikemen, archers and crossbowmen if they wanted to defeat the heavy cavalry of the Western Xia and Jin regimes.

\subsection{The armor of the Tang Dynasty's infantry}

According to Tang Liudian, there were totally thirteen kinds of armor in the Tang Dynasty [14]. The most famous one was called Bright Light Armor (as shown in Figure 8). It was first mentioned by an aristocrat named Caozhi (192-232). In the Tang Dynasty, Bright Light Armor became the necessity of generals, heavy cavalries and elite infantrymen.

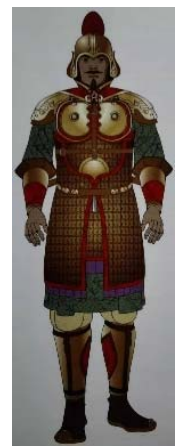

Fig 8 The Bright Light Armor of the Tang Dynasty [19].

However, today's leading role is a kind of heavy lamellar armor named infantry armor. This type of armor appeared in many paintings of the Tang Dynasty (as shown in Figure 9). Besides, archaeologists once discovered an iron helmet of the Tang Dynasty (as shown in Figure 10) in Heilongjiang Province, China. On this basis, some researchers have restored the infantry armor of the Tang Dynasty (as shown in Figure 11). 


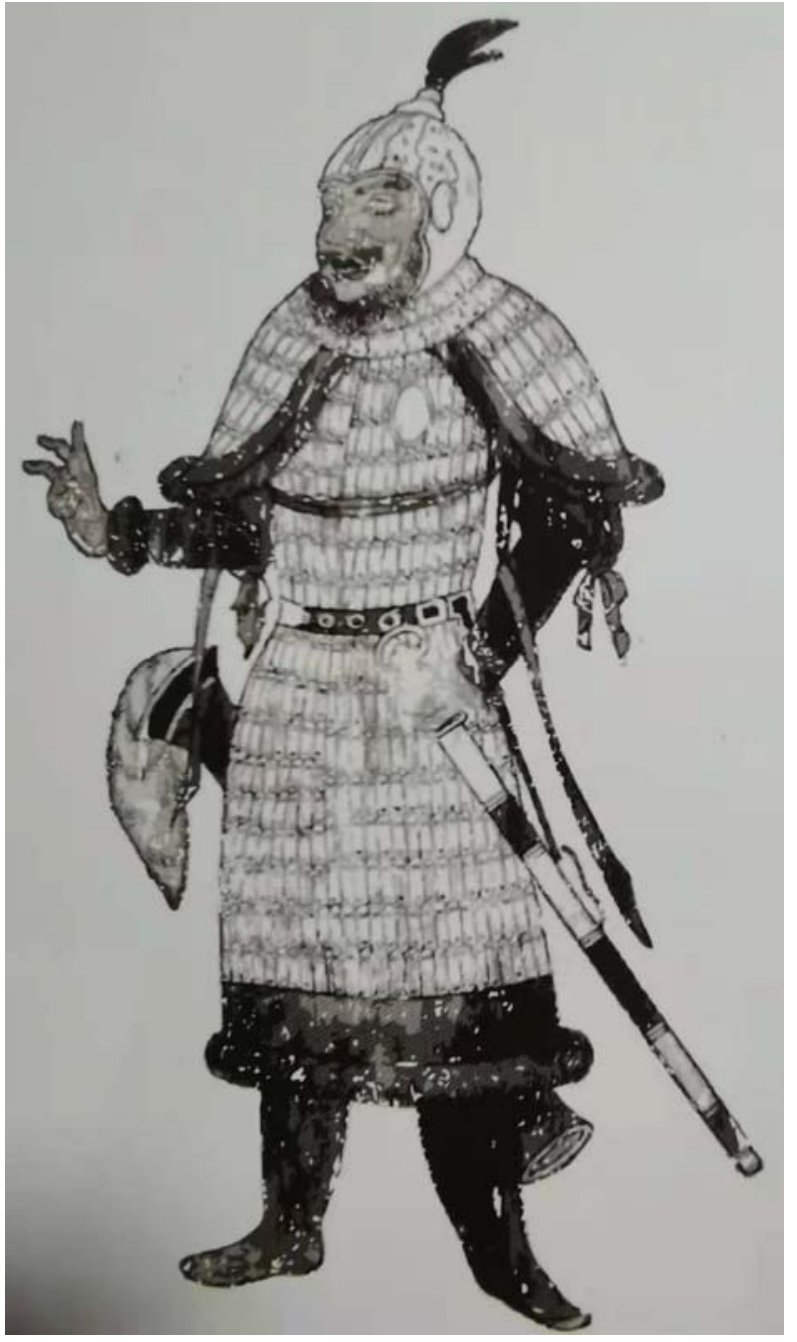

Fig 9 A painting of the Tang Dynasty's warrior [19].

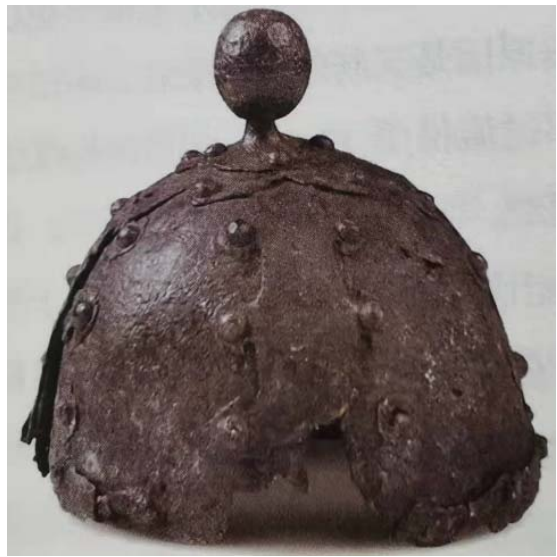

Fig 10 The helmet discovered in Heilongjiang Province, China [20].

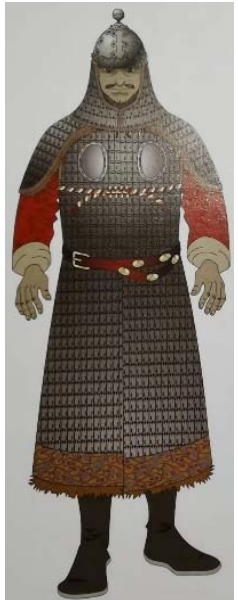

Fig 11 The infantry armor of the Tang Dynasty [19].

Compared with the armor of the previous dynasties, the armor of the Tang Dynasty had a new part named Dunxiang (as shown in Figure 12), which could better protect the soldier's neck. In the Tang Dynasty, a new type of arrow named Chuaner Arrow was invented. This kind of thin arrow could easily puncture hauberk (a kind of armor widely used in Europe and West Asia at that time) [14]. In this situation, heavy lamellar armor was the best choice for the soldiers of the Tang Dynasty.

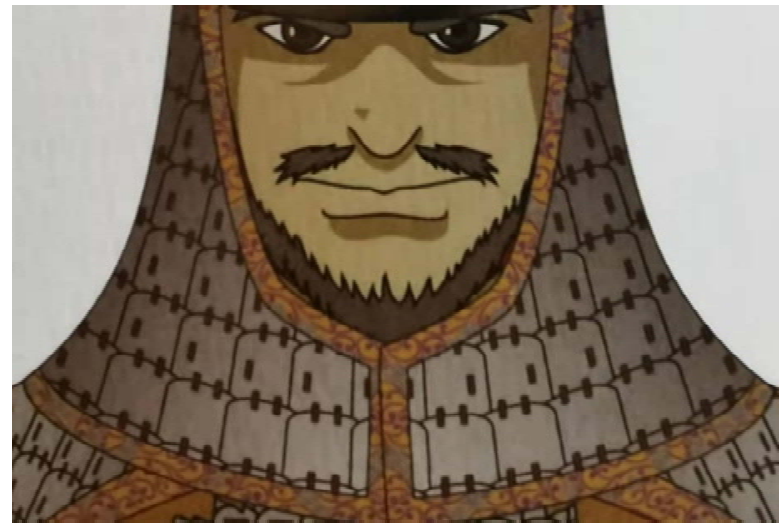

Fig 12 Dunxiang [19].

\section{THE SPECIAL ARMY OF THE LATE TANG DYNASTY}

\subsection{The concept of "Dou"}

As mentioned before, military commissioners' guard armies were the most important military forces in the late Tang Dynasty. Those military commissioners would select the most excellent soldiers from his guard army, building some elite little armies.

When reading the history books about the late Tang Dynasty, we will always see some armies being called "Dou". "Dou" translates literally as "army". These armies were the elite little armies I mentioned before. There were some famous ones such as Heiyun Dou (Dark Cloud 
Army), Yanzi Dou (Wild Geese Army) and Zhaoya Dou (Underlings Army).

Next, I will introduce Dark Cloud Army, the most famous swordsmen of that era.

\subsection{The introduction of Dark Cloud Army}

Yang Xingmi (852-905) was the warlord who built Dark Cloud Army. In 892, Yang defeated another warlord named Sun Ru (?-892) [7]. A large amount of Sun's soldiers surrendered to Yang. Five thousand of them were selected by Yang to build a new army. It was the origin of Dark Cloud Army.

The name Dark Cloud came from the black clothes and black armor worn by these skillful swordsmen [7]. According to Shiguo Chunqiu (1669), they used big swords and charged the enemy line from the front [21]. Soon after, this army became the nightmare of other warlords.

Unfortunately, because of the lack of historical materials, we have no chance to see or restore the swords used by these powerful warriors. However, some sculptures of the Five Dynasties and Ten States period showed the images of some swordsmen who used long swords as their weapons. The sword's length was equal to the length from the feet to the chest or abdomen of an adult (as shown in Figure 13). Since the weapons of the Five Dynasties and Ten States period were the same as those of the late Tang Dynasty, it will be a good reference for us if we want to make a guess about the swords of Dark Cloud Army.

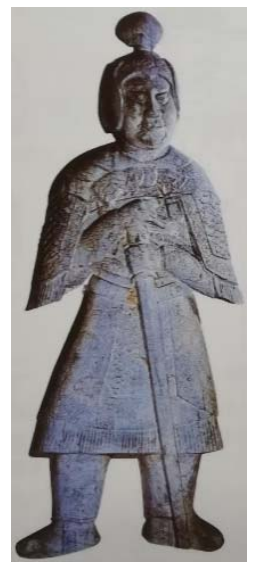

Figure 13 The statue of a swordsman in the Five Dynasties and Ten States period [22].

\section{THE CLASSIC BATTLES OF THE TANG DYNASTY'S INFANTRY}

\subsection{The Battle of Nuozhen River (641)}

\subsubsection{The situation of both sides}

The situation of both sides was as shown in Table 1 .
Table 1. The general situation of the Battle of Nuozhen River

\begin{tabular}{|l|l|l|}
\hline Regime & $\begin{array}{l}\text { The Tang } \\
\text { Dynasty }\end{array}$ & Seyanto \\
\hline Commanders & $\begin{array}{l}\text { Li Ji and } \\
\text { Xue } \\
\text { Wanche }\end{array}$ & Dadushe \\
\hline $\begin{array}{l}\text { The quantity of } \\
\text { soldiers }\end{array}$ & 6,000 & 200,000 \\
\hline Result & Victory & $\begin{array}{l}\text { Most of the } \\
\text { soldiers died on } \\
\text { the way of } \\
\text { retreating } \\
\text { because of the } \\
\text { snowstorm. }\end{array}$ \\
\hline
\end{tabular}

\subsubsection{The process of the battle}

In December 641, General Li Ji (594-669) and his deputy Xue Wanche (?-653) commanded 6,000 soldiers pursuing 30,000 cavalries of Seyanto. Near the Nuozhen River, they met the major force of Seyanto led by Dadushe, the son of Seyanto Khan. Though Seyanto was a nomadic regime, it also owned power infantry and developed some special tactics. The infantry of the Seyanto was divided into many groups. Each group consisted of five people, including a horse watcher and four soldiers. The horse watcher was the leader of the group. These soldiers usually fought dismounted and pursued on their horses.

After the battle started, many war horses of the Tang army were hurt by arrows. Therefore, the heavy cavalries could not charge. General Li asked these cavalries to give up their horses and fight on foot. The cavalries who lost their horses rushed to the enemies with their lances. Their lances(about four meters in length, as shown in Figure 14) and heavy armor made them easily gain an advantage in combat. Under the cover of these temporary pikemen, the rest of the cavalries led by Xue Wanche attacked the horse watchers of Seyanto and got their war horses. Finally, the soldiers of Seyanto lost their morale and had to retreat.

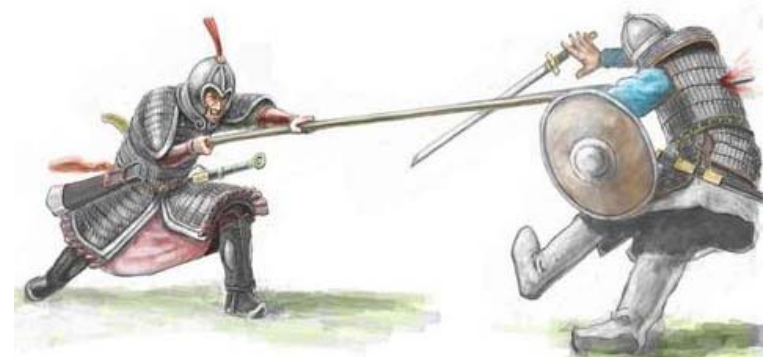

Fig 14 A temporary pikeman of the Tang army attacked a soldier of Seyanto [2]. 


\subsubsection{The analysis of the battle}

In the early Tang Dynasty, since the enemies were the cavalries of the nomads, the commanders of the Tang army usually saw the pikemen as the core of the infantry. Some heavy cavalries who used lances would also fight on foot if necessary. When on the battle field, the pikemen would stand in tight formation, withstanding the assault of enemy's mounted troops. Sometimes, the archers would stand behind them and keep shooting. The cavalry would lie in ambush, waiting for the best time to attack.

The Battle of Nuozhen River was a classic battle of the early Tang Dynasty. The commanders of both sides used temporary infantry as the main force. However, infantry tactic especially the tactic of pikemen was the masterpiece of the Han nationality. Therefore, in this battle, both the commanders and the soldiers of the Tang Dynasty performed much better than their enemies. The advantage of equipment is also of great importance for the Tang army.

\subsection{The Battle of Xiangji Temple (641)}

\subsubsection{The situation of both sides}

The situation of both sides was as shown in Table 1 .

Table 2. The general situation of the Battle of Xiangji Temple

\begin{tabular}{|l|l|l|}
\hline Regime & $\begin{array}{l}\text { The Tang } \\
\text { Dynasty }\end{array}$ & $\begin{array}{l}\text { The rebel forces } \\
\text { of An Qingxu }\end{array}$ \\
\hline Commanders & $\begin{array}{l}\text { Li Siye, Li } \\
\text { Chu, Guo } \\
\text { Ziyi and } \\
\text { Pugu } \\
\text { Huaien }\end{array}$ & An Qingxu \\
\hline $\begin{array}{l}\text { The quantity of } \\
\text { soldiers }\end{array}$ & 154,000 & 100,000 \\
\hline Result & Victory & $\begin{array}{l}\text { Defeated, over } \\
60,000 \text { soldiers } \\
\text { were killed }\end{array}$ \\
\hline
\end{tabular}

\subsubsection{The process of the battle}

In 757, the third year of An-Shi Rebellion, the Tang army led by Li Chu (727-779) and Guo Ziyi (697-781) started a military action to recover Chang'an, the capital of the Tang Dynasty. General Li Siye and his Anxi Army acted as the vanguard of the Tang army. In the north of Xiangji Temple, Li and his soldiers met the rebel forces. The Tang army defeated the vanguard of rebel forces but then attacked by their main force. The soldiers of the Tang army started to flee under the attack of enemies' cavalries. However, what happened next would become one of the most dramatic scenes in the history of ancient China. General Li stood in the front of the formation with his Modao, roaring loudly. Then, every cavalry and their horses he met would be chopped into pieces [8]. Inspired by the heroic performance of their commander, the infantrymen of the Tang army started to charge in tight formation with their glaives and poleaxes [17]. No one could stop them [8]. At the same time, 4,000 elite cavalries commanded by Pugu Huaien (?-765) started to attack the rebel forces from behind. Finally, the rebel forces had to retreat. The next day, Chang'an was recovered.

\subsubsection{The analysis of the battle}

In this battle, General Li's heroic performance was of great importance. It helped the Tang army bring back the morale.

More importantly, General $\mathrm{Li}$ seized the best opportunity to fight back. The commanders of the Tang Dynasty clearly know that melee was the main battlefield of heavy infantry. In the melee, the heavy infantry who were equipped with glaives and poleaxes could easily gain an advantage because the enemies' cavalries couldn't charge in that situation. In the crowd, the spears were unable to exert all of its capabilities. When spears became useless, glaives and poleaxes were much better than common swords. It was a common tactic in the history of China. Another famous general of the Tang Dynasty named Pei Xingjian also used such kind of tactic to defeat the mounted troops of Turkic. The difference was that the military action of Pei was an elaborate fraud. After knowing the Turks liked to attack his transport troops. Pei left the carriages of transport troops behind. What in the carriages were not the grains but the infantrymen who were equipped with glaives. When the Turks rushed to the carriages in chaotic formation, these infantrymen started frenzied killings.

\section{CONCLUSION}

The reason why the infantry of the Tang Dynasty could become one of the most powerful ones in the world was that it had great advantages on equipment, system and tactics. More importantly, both the commanders and the soldiers of the Tang Dynasty had good military quality. Without enough economic power, such an army could not be created. In the field of tactics, the commanders of the Tang Dynasty greatly developed the tactics of ancestors. What's more, the commanders of the empire would use cavalry to assist their infantry. In a word, the advantages of economic power and strategy made the infantry of the Tang Dynasty become powerful and keep its combat effectiveness until the end of the empire. 


\section{REFERENCES}

[1] Tuotuo, The history of Song Dynasty., Zhonghua Book Company, Beijing, 1985.

[2] Zhiwen Fenghuo studio, Illustrated handbook of ancient Chinese weapons, Jilin literature and history Publishing House, Changchun, 2018.

[3] Chen Lebao, The change of crossbows' military function between the Tang and Song Dynasties. Journal of Historical Science, 2013(9): 32-33.

[4] Linghu Defen, The history of the Northern Zhou Dynasty., Zhonghua Book Company, Beijing, 1971.

[5] Liu Xueyao, Turkic Khanates., Shaanxi People's Publishing House, Xi'an, 2019.

[6] Sima Guang, Zizhitongjian[A general reflection for political administration]., Zhonghua Book Company, Beijing, 2011.

[7] Ouyang Xiu., Song Qi, New Tang History Book., Zhonghua Book Company, Beijing, 1975.

[8] Liu Xu, Old Tang History Book., Zhonghua Book Company, Beijing, 1975.

[9] Du You, Tong Dian., Zhonghua Book Company, Beijing, 2016.

[10] Li Quan, Taibai Yinjing., Yuelu Publishing House, Changsha, 2004.

[11] Ban Gu, Han Shu[The history of the Han Dynasty]., Zhonghua Book Company, Beijing, 2007.

[12] Li Yanshou, History of Northern Dynasties., Zhonghua Book Company, Beijing, 1974.

[13] Bo Zhong, Illustrate Chinese traditional weapons., Oriental Press, Beijing, 2010.

[14] Li Linfu, Tang Liudian., Zhonghua Book Company, Beijing, 2014.

[15] Zeng Gongliang., Ding Du, Wujingzongyao[The tactics and weapons of the Song Dynasty]., Commercial Press, Beijing, 2017.

[16] Jia Wei, An analysis of the historical changes of ancient Chinese armor. Master, Tianjin Normal University, Tianjin, June 2010.

[17] Huang Daozhou, Guangmingjiangzhuan[The famous generals of ancient China]., Catalogs and Documentations Publishing House, Beijing, 1986.

[18] Wang Saishi., Liu Xi, The archery and hunting of the Tang Dynasty, Journal of Chengdu Sport University, 1986(2): 24.

[19] Chen Dawei, Illustrate Ancient Chinese Armour., Chemical Industry Publishing House, Beijing, 2017.
[20] Zhou Yu, Illustrated handbook of the history of Chinese armor., Jiangsu Phoenix Literature and Art Publishing, Nanjing, 2020.

[21] Wu Renchen, Shiguo Chunqiu [The history of the Ten States period]., Zhonghua Book Company, Beijing, 2010

[22] Liu Yonghua, The ancient Chinese military uniform., Tsinghua University Press, Beijing, 2013 